\title{
Effect of Humic Acid and Bacterial Manure on Distribution of Heavy Metals in Different Organs of Maize
}

\author{
Tao Li, Hongyan Cheng, Kokyo Oh, and Shigeo Hosono
}

\begin{abstract}
Heavy metal contamination of soil may pose risks to human health and ecosystem environment. Phytoremediation is a low-cost and ecologically sustainable way to remediate heavy metal contaminated soils. As most of the heavy metal accumulator plants are low biomass producers, we selected maize as our experimental phytoremediation plant, which can both produce large useful biomass and remediate heavy metal contaminated soils. The effect of humic acid and bacterial manure on heavy metal accumulation in different organs of maize was studied in this paper, in order to investigate whether the fertilizer application has an effect on phytoremediation efficiency. The results showed that $\mathrm{Cu}, \mathrm{Pb}$ and $\mathrm{Zn}$ contents in the organs of maize generally followed the order root>stem $\approx$ leaf $>$ grain. Application of humic acid and bacterial manure improved the contents of $\mathrm{Cu}, \mathrm{Zn}$ and $\mathrm{Pb}$ in different organs compared with those without fertilizer application. Maize with humic acid application generally had higher contents of $\mathrm{Cu}, \mathrm{Zn}$ and $\mathrm{Pb}$ in the organs than that with bacterial manure application. This study indicated that fertilizer application was possibly one of the efficient ways to enhance the efficiency of soil phytoremediation.
\end{abstract}

Index Terms-Soil contamination, heavy metal, phytoremediation, humic acid, bacterial manure, maize.

\section{INTRODUCTION}

Soil pollution with heavy metals such as $\mathrm{Cd}, \mathrm{Cu}, \mathrm{Zn}$ and $\mathrm{Pb}$ is a universal problem because these metals are indestructible and most of them have toxic effects on living organisms. The heavy metals in environment affect human health are mainly through the food chain [1]. In Japan, the itai-itai disease was aroused in the late 1960s as the people ate the rice grown in the Cd polluted area, arousing worldwide concerns [2].

Phytoremediation is a biological technology process that utilizes the green plants or specially selected and engineered metal-accumulating plants to enhance degradation and removal of organic or inorganic contaminants in contaminated soil, groundwater or sediment [3], [4]. Phytoremediation takes advantage of the remarkable ability of plants to concentrate elements and compounds from the environment and to metabolize various molecules in their tissues. Many studies have shown that phytoremediation is a low cost and eco-friendly technology compared with the conventional physicochemical methods [5], [6].

Manuscript received October 10, 2013; revised December 10, 2013. This work was jointly supported by Shanxi International Cooperation Project (No. 2013081002) and the Grant-in-Aid for Scientific Research (B, No. 23405049), Japan Society for the Promotion of Science.

Tao Li and Hongyan Cheng are with the College of Resources and Environment, Shanxi Agricultural University, Shanxi, China (e-mail: ndlitao@126.com; ndchenghy@163.com).

Kokyo Oh and Shigeo Hosono are with Center for Environmental Science in Saitama, 914 Kamitanadare, kazo, Saitama 347-0115, Japan (e-mail: o.kokyo@pref.saitama.lg.jp; hosono.shigeo@pref.saitama.lg.jp).
Hyperaccumulator plants are extensively studied for application in phytoremediation. Hyperaccmulators can have heavy metal concentrations in their dry biomass that are 100 times higher than non-hyperaccumulators growing in the same soil [4]. These plants have several beneficial characteristics for phytoremediation, but they usually grow slowly and produce low biomass. For example, thlaspi caerulescens, one of the best-known metal hyperaccumulator, only produces $2-5 \mathrm{Mg} \mathrm{ha}^{-1}$ [7], [8]. It is possibly a approach way to use high biomass crops like maize as phytoremediation plants to overcome these shortcomings. It is well known maize (Zea mays L.) is one of the most widely grown cereal crop in the world that grows rapidly in a large rang of soil and clime types. It grows quickly, produces extensive root system as well as large shoot biomass and very high grain yield. At the same time, maize roots have higher enrichment of various heavy metals [9]. It is not only used as cereal foods, but also used as a feedstock for the production of bioethanol [10], [11]. In the United States, about 332 million metric tons of maize was grown annually, in which approximately $40 \%$ of them- 130 million tons-is used for bioethanol [12]. Therefore, over the recent years, maize has also been consideration for utilization in phytoremediation of contaminated soil.

Humic acid widely exists in soil, lakes, rivers and oceans, and is the main component of soil organic matter. It is also a natural soil conditioner, which contains a large number of carboxyl, phenolic hydroxyl and other active groups to improve the formation of soil microbial community. It increases the utilization rate of $\mathrm{N}, \mathrm{P}, \mathrm{K}$ and trace elements to stimulate the growth of the crops and enhance the resistance of crops [13], [14]. Bacterial manure is an environmental friendly fertilizer, which has been widely used for promotion of crop production and conservation of soil quality [15], [16] Application of humic acid and bacterial manure not only effectively improve soil physical and chemical properties, to provide a more suitable environment for plant growth, but also significantly reduce the use amount of chemical fertilizers and pesticides in soils [17]. As an important way for increasing yield in agricultural production, fertilization of humic acid and bacterial manure also can accelerate remediation of contaminated soil by heavy metals [18] Studies have shown that in heavy metal stress, mycorrhizal fungi through secretions change the rhizosphere environment, and affect the bioavailability of heavy metals and toxicity of heavy metal to plants [19]. On the other hand, by changing the distribution of heavy metals in plants, mycorrhizal fungi can improve the tolerance of plant to heavy metals, and promote the heavy metal transfer from root to aboveground [20], [21].

There are many researches about effects of nitrogen, 
phosphorus and potassium fertilizations on plant heavy metal uptake, however, the researches about effect of humic acid and bacterial manure on absorption and distribution of heavy metals in plants are still few. Therefore we carried out a pot experiment to study the humic acid and bacterial manure on distribution of heavy metals $(\mathrm{Pb}, \mathrm{Cu}, \mathrm{Zn})$ in different organs of maize.

\section{MATERIALS AND METHODS}

\section{A. Soils and Plant}

The soil was collected from Shanxi Agricultural University experiment station, which was a calcareous cinnamon according to Classification and codes for Chinese soil (GB/T17296-2000) [22]. The physic-chemical properties of the soil are shown in Table I. The maize variety Changyu 16 was used in the experiment.

TABLE I: PHYSIC-CHEMICAL PROPERTIES OF THE EXPERIMENTAL SOIL

\begin{tabular}{ccccc}
$\mathrm{pH}$ & $\begin{array}{c}\text { Organic } \\
\text { matter } \\
\left(\mathrm{g} \mathrm{kg}^{-1}\right)\end{array}$ & $\begin{array}{c}\text { Available } \\
\text { phosphorus } \\
\left(\mathrm{mg} \mathrm{kg}^{-1}\right)\end{array}$ & $\begin{array}{c}\text { Available } \\
\text { nitrogen } \\
\left(\mathrm{mg} \mathrm{kg}^{-1}\right)\end{array}$ & $\begin{array}{c}\text { Available } \\
\text { potassium } \\
\left(\mathrm{mg} \mathrm{kg}^{-1}\right)\end{array}$ \\
\hline 7.92 & 3.51 & 60.93 & 2.06 & 126.2 \\
\hline
\end{tabular}

\section{B. The Modulation of Contaminated Soil}

The soil contamination was made by the chemicals with addition of $\mathrm{Pb}, \mathrm{Cu}$, and $\mathrm{Zn}$, and mixed thoroughly. Each pot (10 kg soil) was added $4.991 \mathrm{~g}\left(\mathrm{CH}_{3} \mathrm{COO}\right)_{2} \mathrm{~Pb} \cdot 3 \mathrm{H}_{2} \mathrm{O}$ (Tianjin Fucheng Chemical Reagent Factory production, AR, contain not less than $99.0 \%$, molecular weight 331.21) for $\mathrm{Pb}$ contaminated treatment, $2.539 \mathrm{~g} \quad \mathrm{CuSO}_{4} \cdot 5 \mathrm{H}_{2} \mathrm{O}$ (Tianjin Fucheng Chemical Reagent Factory production, AR, contain not less than $99.0 \%$,molecular weight 249.68) for $\mathrm{Cu}$ contaminated treatment, and $7.339 \mathrm{~g} \mathrm{ZnSO}_{4} \cdot 7 \mathrm{H}_{2} \mathrm{O}$ (Tianjin Fucheng Chemical Reagent Factory production, AR, contain not less than $99.5 \%$,molecular weight 287.56) for $\mathrm{Zn}$ contaminated treatment, respectively. The final concentrations of the experimental soil were $350 \mathrm{mg} \mathrm{kg}^{-1}$ for $\mathrm{Pb}, 100 \mathrm{mg} \mathrm{kg}^{-1}$ for $\mathrm{Cu}$ and $300 \mathrm{mg} \mathrm{kg}^{-1}$ for $\mathrm{Zn}$.

\section{Pot Culture and Treatments}

The pot culture experiment was conducted in Shanxi Agricultural University $\left(37^{\circ} 12^{\prime} \sim 37^{\circ} 32^{\prime} \mathrm{N}, 111^{\circ} 28^{\prime} \sim 111^{\circ} 111^{\prime}\right.$ E). Initially the seeds of the maize were grown in pots in a green house. Each pot was filled with $10 \mathrm{~kg}$ contaminated soil. The average temperature of green house was approximately $28{ }^{\circ} \mathrm{C}$ in the day time and $20{ }^{\circ} \mathrm{C}$ at night.

TABLE II: THE TREATMENTS IN THE EXPERIMENT

$\mathrm{Pb}$ contaminated soil $\quad \mathrm{Cu}$ contaminated soil $\mathrm{Zn}$ contaminated soil

\begin{tabular}{ccc}
\hline $\mathrm{Pb}(\mathrm{CK})$ & $\mathrm{Cu}(\mathrm{CK})$ & $\mathrm{Zn}(\mathrm{CK})$ \\
$\mathrm{Pb}+\mathrm{J}$ & $\mathrm{Cu}+\mathrm{J}$ & $\mathrm{Zn}+\mathrm{J}$ \\
$\mathrm{Pb}+\mathrm{F}$ & $\mathrm{Cu}+\mathrm{F}$ & $\mathrm{Zn}+\mathrm{F}$ \\
\hline
\end{tabular}

As shown in Table II, for each heavy metal the experimental treatments were CK (contaminated soil), $\mathrm{CK}+$ $\mathrm{F}$ (10 kg contaminated soil mixed with $5 \mathrm{~g}$ humic acid), $\mathrm{CK}+$ $\mathrm{J}$ (10 kg contaminated soil mixed with $5 \mathrm{~g}$ bacterial manure). The experiment was randomly arranged with three replicates for each treatment.

\section{Heavy Metal Analysis}

Each plant sample was weighted $0.5 \mathrm{~g}$ and put it into porcelain crucible, then placed into a muffle furnace at $525{ }^{\circ} \mathrm{C}$ for ashing 3 hours, and make the color to gray. After cooling, the sample was dissolved with $1: 1 \mathrm{HNO}_{3}$, filtered with filter paper, and transfer to the $50 \mathrm{ml}$ flask. Heavy metal detection was made using ICP (PE5300DV America) [23].

\section{E. Data Analysis}
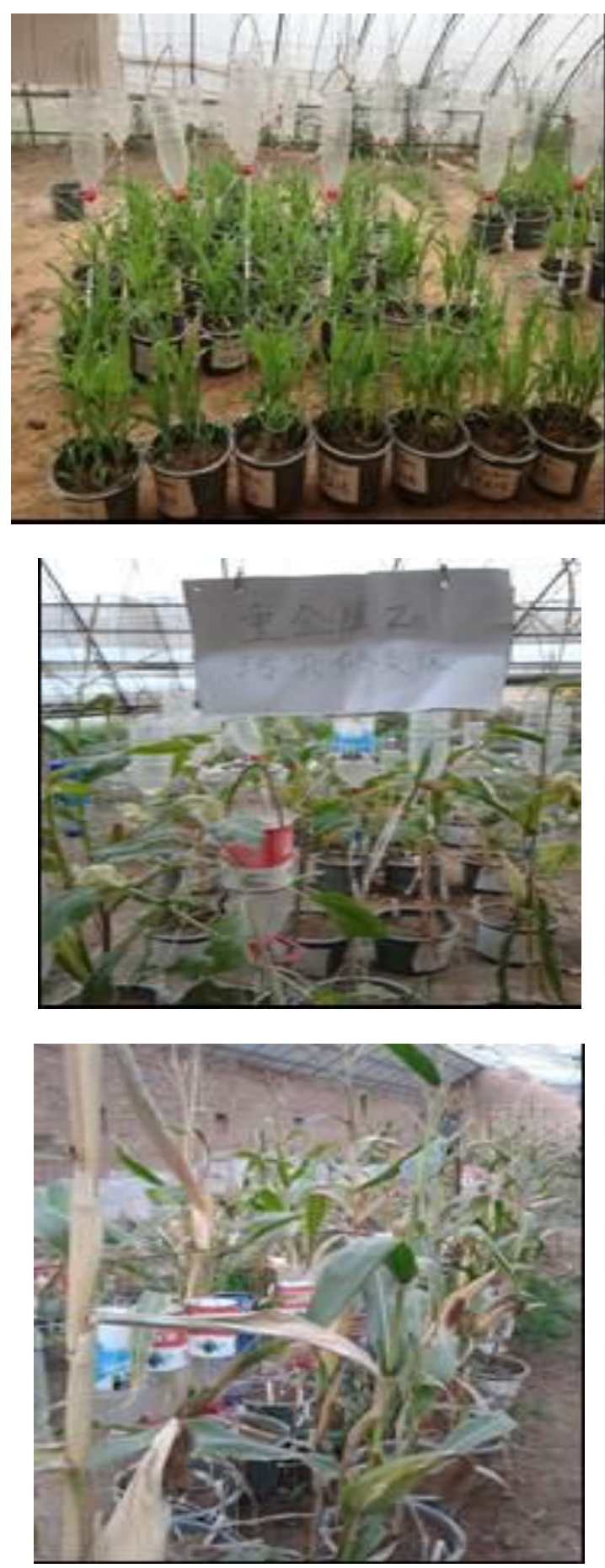

Fig. 1. Pictures of the pot experiment in the greenhouse. 
All experiments were conducted using a completely randomized design. Microsoft Excel 2003 and Date Processing System (DPS) were used for data analysis. Means with different letters in the same column differ significantly at $P<0.05$ (see Fig. 1).

\section{RESULTS AND DISSCUSSION}

\section{A. Distribution of Zn in Different Organs of Maiz}

Zn concentrations in different parts of plants were shown in Table III. Quite different concentration was observed under $\mathrm{Zn}\left(300 \mathrm{mg} \mathrm{kg}^{-1}\right)$ stress with different application of the fertilizers. The high-to-low trend of $\mathrm{Zn}$ content in each fertilizer was root $>$ shoot or leaf $>$ grain. The $\mathrm{Zn}+\mathrm{F}$ treatment showed the highest $\mathrm{Zn}$ concentration in root, shoot and leaf, which was increased about $19.89 \%, 66.42 \%, 22.35 \%$ than $\mathrm{Zn}$ $\mathrm{CK}$, respectively. In $\mathrm{Zn}+\mathrm{J}$ treatment, $\mathrm{Zn}$ concentration in root, shoot, leaf and grain increased $15.14 \%, 62.42 \%$, $32.51 \%, 32.87 \%$ than $\mathrm{Zn} \mathrm{CK}$, respectively. The Zn CK treatment showed the lowest $\mathrm{Zn}$ contents in root, shoot and grain.

TABLE III: ZN CONCENTRATION IN DIFFERENT PARTS OF PLANTS (MG KG ${ }^{-1}$ )

\begin{tabular}{|c|c|c|c|l|}
\hline & Root & Shoot & Leaf & Grain \\
\hline $\mathrm{ZnCK}$ & $509.2 \mathrm{~b}$ & $72.49 \mathrm{de}$ & $126.7 \mathrm{cde}$ & $28.59 \mathrm{e}$ \\
\hline $\mathrm{Zn+J}$ & $600.0 \mathrm{ab}$ & $192.9 \mathrm{~cd}$ & $187.7 \mathrm{~cd}$ & $42.59 \mathrm{e}$ \\
\hline $\mathrm{Zn+F}$ & $635.6 \mathrm{a}$ & $215.9 \mathrm{c}$ & $241.7 \mathrm{c}$ & $31.79 \mathrm{e}$ \\
\hline
\end{tabular}

Means with same letter are not significantly different at the 5\% level.

The total $\mathrm{Zn}$ contents in maize in different treatments also showed that the $\mathrm{Zn}+\mathrm{F}$ treatment was the highest content (173.5 $\mathrm{mg} \mathrm{kg}^{-1}$ ), while those of $\mathrm{Zn} \mathrm{CK}$ was the lowest (Fig. 2). The increase rates of total $\mathrm{Zn}$ contents for $\mathrm{Zn}+\mathrm{F}$ and $\mathrm{Zn}+\mathrm{J}$ were $23.8 \%$ and $13.6 \%$ compared to that of $\mathrm{Zn} \mathrm{CK}$, respectively.

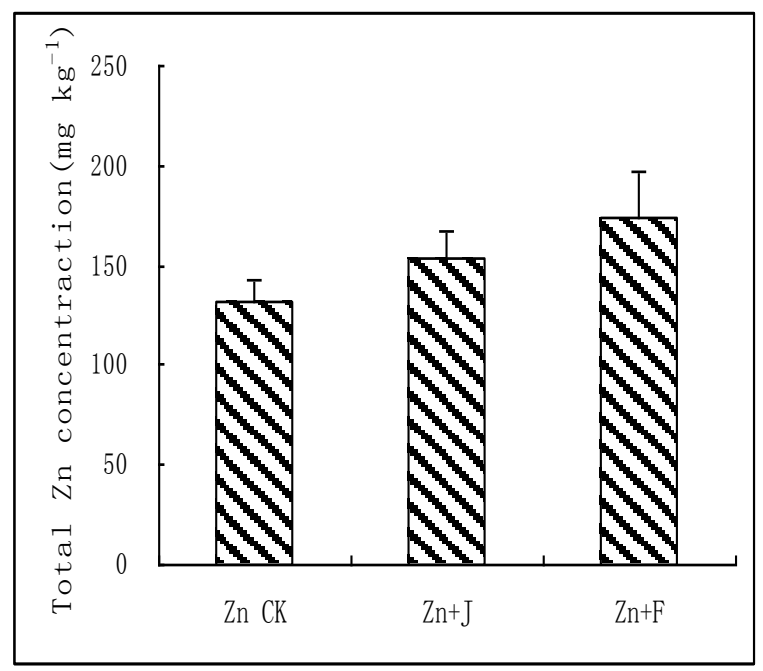

Fig. 2. Zn concentration in the whole plant under different treatments.

This is possibly caused by influenced by the increase of mobility of heavy metals in the soil with application of HA and BM, as Tian reported that mycorrhizal inoculation with application of chelating agents, can promote the remediation efficiency of maize to heavy metals [24]. Humic acid affect many aspects of plant physiological activities, including crop growth, uptake of nutrient elements, photosynthesis, respiration and activities of enzymes [17].

\section{B. Distribution of $C u$ in Different Organs of Maize}

$\mathrm{Cu}$ concentrations in different parts of plants are given in Table IV. The distribution of $\mathrm{Cu}$ content in different organs is root>leaf $>$ shoot>grain. The $\mathrm{Cu}+\mathrm{F}$ treatment showed the highest $\mathrm{Cu}$ concentration in root, shoot and leaf, which was increased $62.36 \%, 9.85 \%, 27.87 \%$ than $\mathrm{Cu} \mathrm{CK}$, respectively. The $\mathrm{Cu}+\mathrm{J}$ treatment showed the highest $\mathrm{Cu}$ concentration in grain, which increased about $11.95 \%$ than $\mathrm{Cu}$ CK.

The increase rates of $\mathrm{Cu}+\mathrm{F}$ and $\mathrm{Cu}+\mathrm{CK}$ ranged from $0.67 \%$ to $62.4 \%$ against $\mathrm{Cu} \mathrm{CK}$. The total $\mathrm{Cu}$ content in different treatments also showed the same trend with $\mathrm{Zn}$ content (Fig. 3). A series of physical, chemical and biological reactions occur after applied fertilizer, leading to morphological change of heavy metals [25]-[28]. The reason of humic acid and bacterial manure fertilization increased the content of $\mathrm{Cu}$ in maize possibly due to that humic acid and bacterial manure increased mobility of soil $\mathrm{Cu}$.

TABLE IV: Cu CONCENTRATION IN DIFFERENT PARTS OF PLANT (MG KG ${ }^{-1}$ )

\begin{tabular}{|c|c|c|c|c|}
\hline & Root & Shoot & Leaf & Grain \\
\hline $\mathrm{Cu} \mathrm{CK}$ & $14.07 \mathrm{bc}$ & $8.88 \mathrm{~cd}$ & $11.26 \mathrm{~cd}$ & $5.01 \mathrm{~d}$ \\
\hline $\mathrm{Cu}+\mathrm{J}$ & $19.82 \mathrm{~b}$ & $8.94 \mathrm{~cd}$ & $10.01 \mathrm{~cd}$ & $5.69 \mathrm{~d}$ \\
\hline $\mathrm{Cu}+\mathrm{F}$ & $37.38 \mathrm{a}$ & $9.85 \mathrm{~cd}$ & $15.61 \mathrm{bc}$ & $5.43 \mathrm{~d}$ \\
\hline
\end{tabular}

Means with same letter are not significantly different at the $5 \%$ level.

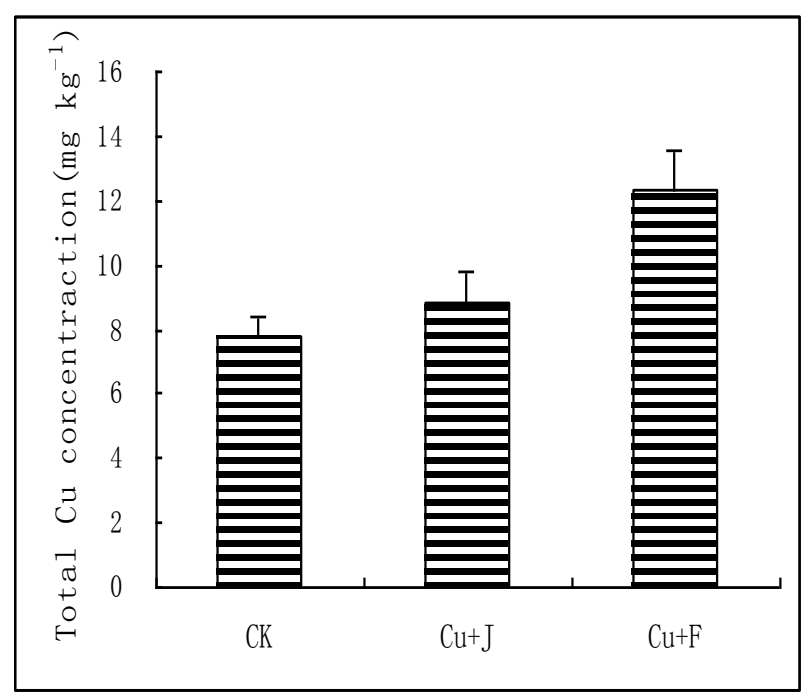

Fig. 3. $\mathrm{Cu}$ concentration in the whole plant under different treatments.

\section{Distribution of $\mathrm{Pb}$ in Different Organs of Maize}

The results indicated that under $\mathrm{Pb}\left(350 \mathrm{mg} \mathrm{kg}^{-1}\right)$ stress, the soil with application of humic acid and bacterial manure promoted the $\mathrm{Pb}$ content in maize (Table $\mathrm{V}$ ). The increase 
rates ranged from $0.78 \%$ to $61.96 \%$ against $\mathrm{Pb} \mathrm{CK}$. The $\mathrm{Pb}$ contents of different parts of maize increased compared with $\mathrm{Pb} \mathrm{CK}$. The $\mathrm{Pb}+\mathrm{F}$ treatment showed the highest $\mathrm{Pb}$ content, and $\mathrm{Pb} \mathrm{CK}$ showed the lowest $\mathrm{Pb}$ content. The total $\mathrm{Pb}$ content in different treatments also showed the same trend with that of $\mathrm{Zn}$ and $\mathrm{Cu}$ content as mentioned above (Fig. 4). The $\mathrm{Pb}+\mathrm{F}$ treatment showed the highest total $\mathrm{Pb}$ content, which was increased $16.91 \%$ and $4.45 \%$ than $\mathrm{Pb} \mathrm{CK}$.

TABLE V: PB CONCENTRATION IN DifFERENT PARTS OF PLANTS (MG KG ${ }^{-1}$ )

\begin{tabular}{|c|c|c|c|c|}
\hline & Root & Shoot & Leaf & Grain \\
\hline $\mathrm{Pb} \mathrm{Ck}$ & $774.8 \mathrm{~b}$ & $6.93 \mathrm{de}$ & $6.74 \mathrm{de}$ & $3.58 \mathrm{e}$ \\
\hline $\mathrm{Pb}+\mathrm{J}$ & $780.9 \mathrm{~b}$ & $9.53 \mathrm{~d}$ & $7.19 \mathrm{~d}$ & $6.37 \mathrm{de}$ \\
\hline $\mathrm{Pb}+\mathrm{F}$ & $905.1 \mathrm{a}$ & $23.69 \mathrm{c}$ & $23.17 \mathrm{c}$ & $9.41 \mathrm{~d}$ \\
\hline
\end{tabular}

Means with same letter are not significantly different at the $5 \%$ level.

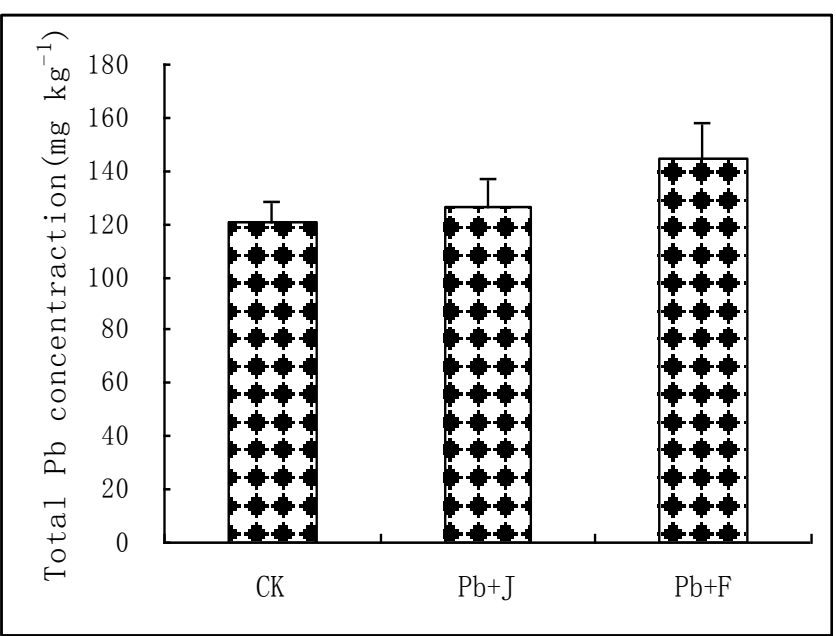

Fig. 4. $\mathrm{Pb}$ concentration in the whole plant under different treatments.

In summary, the application of humic acid and bacterial manure increased the concentrations of $\mathrm{Zn}, \mathrm{Cu}$ and $\mathrm{Pb}$ in maize. This possibly due to bacterial manure and the humic acid increased the availability of $\mathrm{Zn}, \mathrm{Cu}$ and $\mathrm{Pb}$, thus increased their uptake and concentration in maize.

\section{CONCLUSIONS}

The results showed that contents sequence of $\mathrm{Cu}, \mathrm{Pb}$ and $\mathrm{Zn}$ in the different organs of maize was root $>$ stem $\approx$ leaf $>$ grain. Application of humic acid and bacterial manure improved the content of $\mathrm{Cu}, \mathrm{Zn}$ and $\mathrm{Pb}$ in different maize organs. The humic acid application showed larger contents of $\mathrm{Cu}, \mathrm{Zn}$ and $\mathrm{Pb}$ in different organs than bacterial manure application. The uptake to $\mathrm{Pb}$ was more easily promoted with application of humic acid. According to these results, the humic acid and bacterial manure application is possibly a way to enhance the efficiency of phytoremediation. Phytoremediation efficiency may be promoted through selection of fertilizer types. Our further study will focus on finding more environmental friendly fertilizers and study their suitable concentration for plant growth in contaminated soils, through which to improve the efficiency of phytoremediation.

\section{REFERENCES}

[1] A. Piechalak, B. Tomaszewska, D. Baralkiewicz et al., "Mulation and detoxification of lead ions in legumes," Phytochemistry, vol. 60, pp. 153-162, 2002.

[2] M. Ikeda, T. Ezaki, T. Tsukahara, and J. Moriguchi, "Dietary cadmium intake in pilluted and non-polluted areas in Japan in the past and in the present," International Archives of Occupational and Environmental Health, vol. 77, no. 4, pp. 227-234, 2004.

[3] D. E. Salt, R. D. Smith, and I. Raskin, "Phytoremediationt," Annual Review of Plant Physiology and Plan Molecular Biology, vol. 49, pp. 643-668, 1998.

[4] A. Van Der Ent, A. J. M. Baker, R. D. Reeves, A. J. Pollard, and H. Schat, "Hyperaccumulators of metal and metalloid trace elements: Facts and fiction," Plant Soil, vol. 362, pp. 319-334, 2013.

[5] R. Kamath, J. A. Rentz, J. L. Schnoor, and P. J. J. Alvarez, "Phytoremediation of hydrocarbon-contaminated soils: principles and applications," Studies in Surface Science and Catalysis, vol. 151, pp. 447-478, 2004

[6] K. Oh, T. Li, H. Y Cheng, X. F. Hu, Q. Lin, and Y. H. Xie, “A primary study on assessment of phytoremediation potential of biofuel crops in heavy metal contaminated soil," Applied Mechanics and Materials, vol. 295-298, pp. 1135-1138, 2013

[7] A. Scragg, Environmental Biotechnology, 2nd ed. Oxford University Press, Oxford, 2006

[8] R. A. Wuana1 and F. E. Okieimen, "Phytoremediation potential of maize (Zea mays L.). A review," African Journal of General Agriculture, vol. 6, pp. 275-287, 2010.

[9] L. Wei, Y. H. Chen, M. Qian, Z. G. Zhen, and X. D. Li, "The potential of biodegradable chelate EDDS for phytoextraction of heavy metals from contaminated soils," Nanjing Agricultural University, vol. 2, pp. 33-38, 2006

[10] Z. Y. Zhu and L. M. Yu, "Effects of fuel ethanol production by maize on the agricultural products market in U.S," Food and Nutrition in China, vol. 6, pp. 48-51, 2012.

[11] D. Zhang, C. H. Ding, L. T. Li, and H. Feng, "Fuel ethanol production from corn straw," Liquor Making, vol. 5, pp. 56-58, 2006.

[12] US Approves Corn Modified for Ethanol, The New York Times, February 11, 2011

[13] T. J. Ru and J. S. Wang, "Humic acid and the development og humic acid-containing fertilizer," Phosphate and Compound Fertilizer, vol. 4, no. 22, pp. 51-53, 2007.

[14] W. Li, L. Zou, S. Zhu, and F. Qian "The general statement on humic acid application in recent ten years," Humic Acid, vol. 3, pp. 3-8, 2006.

[15] C. H. Yu, Q. X. Xu, and Z. F. Meng, "The effect of bio-bact erial manure on vegetable quality," Tianjin Agricultural Sciences, vol. 2, pp. 20-22, 2000.

[16] H. Y. Li, J. Wang, F. T. Lv, and H. X. Wang, "The development ostatus and prospect of microbial fertilizer," Chinese Countryside Well-off Technology, vol. 10, pp. 53-54, 2008.

[17] Y. L. Chen, "Influences of humic acids on physioligocal activities of plants," Chinese Bulletin of Botany, vol. 1, pp. 64-72, 2000.

[18] Y. M. Xu, D. S. Lin, J. B. Lu, and D. Jia, "Effects of organic manure and molecular sieve material on speciation of $\mathrm{Cd}, \mathrm{Pb}, \mathrm{Cu}$ in soil and bioavailability," Journal of Agro-Environment Science, vol. 25, pp. 326-330, 2006.

[19] F. Y. Wang, X. G. Lin, and R. Yin, "Influence of arbuscular mycormhizal fungi on growth and Cu uptake of Elsholtiza splendens," Environmental Science, vol. 5, pp. 174-180, 2005.

[20] S. Citterio, N. Prato, and P. Fumagalli, "The arbuscubar mycorrhizal fungus Clomus mosseae induces growth and metal accumulation changes in Cannabis sativa L.," Chemosphere, vol. 59, pp. 21-29, 2005.

[21] X. L. Li and P. Christie, "Changes in soil solution $\mathrm{Zn}$ and $\mathrm{pH}$ and uptake of $\mathrm{Zn}$ by arbuscular mycorrhizal red clover in $\mathrm{Zn}$-contaminated soil," Chemosphere, vol. 42, no. 2, pp. 201-207, 2001.

[22] China National Institute of Standardization, "Classification and codes for Chinese Soil (GB/T17296-2000)," China Standard Press, 2009

[23] R. K Lu, "Soil agricultural chemical analysis method," China Agricultural Science Press, pp. 298-299, 1999

[24] S. Tian, Y. Z. Ding, and X. H. Ju, "Study on the response of maize to heavy metal stress and its applications in phytoremediation," Anhui Agricultural Sciences, vol. 5, no. 37, pp. 2208-2210, 2009.

[25] Y, L. Zhang and Q. R. Shen, "Effects of organic manure on the amelioration of Cd - polluted soil," Acta Pedologica Sinica, vol. 2, no. 38 , pp. 212-218, 2001. 
[26] Y. Q. Zu, Y. Li, H. Y. Chen et al., "Research on factors influencing concentrations of $\mathrm{Pb}, \mathrm{Cd}, \mathrm{Cu}$ and $\mathrm{Zn}$ in vegetables," Agro-Environment Science, vol. 3, no. 22, pp.289-292, 2003.

[27] G. F. Yu, F. Gui, X. Liang, L. Sun et al., "A review for effect of organic substances on the availability of cadmium in soils," Acta Ecologica Sinica, vol. 5, no. 22, pp. 770-776, 2002.

[28] R. M. Li and G. Wang, "Effects of complexation of calcium, magnesium, phosphate with organic manure on $\mathrm{Cd}, \mathrm{Pb}$ up take by crop," Soil and Environmental Sciences, vol. 4, no. 11, pp. 348-351, 2002.

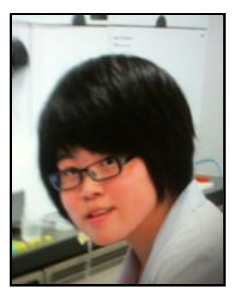

Tao $\mathbf{L i}$ is a master course student of Shanxi Agricultural University, China. She is studying and doing research assistant on environmental science. She has been invited to do international cooperation research in Japan for two times as she is an excellent student with very cooperative personal character as well as active and hardworking spirit.

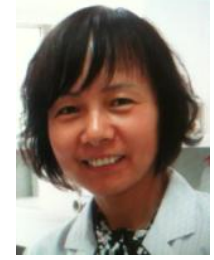

Hongyan Cheng is the corresponding author and she is a professor of Shanxi Agricultural University, China. Her current research interest is on soil environment, phytoremediation, and chemical analysis. She has published more than 30 publications, and actively cooperated with overseas research institutions.

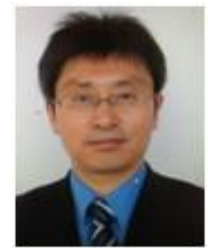

Kokyo Oh is the corresponding author and he is a senior researcher in Center for Environmental Science in Saitama, Japan. He graduated with his M.Sci. degree and Ph.D. degree in Chinese Academy of Sciences, and was honored as a STA research fellow by Japan government. The research areas include soil environment, water environment conservation environmental chemistry, and atmospheric environment. His current research is mainly on soil remediation, environmental agronomy, atmospheric environment and water environment conservation. He has published more than 90 publications. 